\title{
Livelihood, Dependence on Forest and Its Degradation: Evidence from Meghalaya
}

\author{
Utpal Kumar De ${ }^{1}$ \\ ${ }^{1}$ Department of Economics, North-Eastern Hill University, India \\ Correspondence: Utpal Kumar De, Department of Economics, North-Eastern Hill University, India. Tel: \\ 91-943-610-2066. E-mail: de_u@yahoo.com
}

Received: June 11, 2012 Accepted: August 4, 2012 Online Published: August 20, 2012

doi:10.5539/enrr.v2n3p96

URL: http://dx.doi.org/10.5539/enrr.v2n3p96

\begin{abstract}
The linkages between population growth, pattern of livelihood and dependence as well as degradation of forests have long been the subject of debate and concern. It is thus important to investigate to what extent does the growth of population, poverty and livelihood affect the neighbouring forest resources or how are they affected by the degradation of forests. Various assessments have assigned the major responsibility in the loss of forest cover at various places either to population growth or logging, or other commercial resource extraction, including the spread of cattle ranches. The objective of this paper is to unfold the nature of dependence on forest and factors affecting degradation of forest in Meghalaya in an interlinking fashion. The analysis reveals that family size, incidence of poverty, cultivation practice, remoteness of the area and consumption or livelihood pattern have important impact on the extraction of forest resources. Education helps in conservation and sustainable use of the forest resources. Broadly, there is important inter-linkage between population growth, incidence of poverty and degradation of forest in the region.
\end{abstract}

Keywords: livelihood, dependence on forest, degradation of forest, factors affecting dependence and degradation of forest, Meghalaya

\section{Introduction}

The livelihood pattern, socio-economic background of the inhabited population, are closely associated with their dependence on the ambient natural resources including forests and thus related to the nature of degradation of such resource across the places. Despite being a renewable natural resource, degradation of forest has been observed across India and various assessments have related this either to population growth (especially the growth of landless farmers on the perimeter of forests) or logging, or other commercial resource extraction, including the spread of cattle ranches and in general economic growth of the region (Engelman, 1997).

The population, poverty and environment linkage is both direct and indirect. Some argued that low living standards in the rural areas contribute to rising pressure on natural resources, which in turn aggravate poverty. Whereas, others argued that environmental (here forest) degradation and rapid population growth are both cause and consequence of poverty. When a growing population increasingly impinges on a resource base, which is inelastic in supply (e.g. land, major minerals and also forest to a certain extent), the diminishing per capita availability of resources causes a negative impact on their living standards (Reidhead et al., 1997).

Maintaining a balance between the productive potential of the ecosystem with minimal or no damage to its environment and the increase in human welfare has become a very critical issue in any economy. Here, the focus on increasing production to cope with the growing population should ensure that production itself should not degrade resources beyond their regenerative capacity. The interrelationship between population and environment is a complex one. People modify their environment, and in turn population is affected by changes in the environmental conditions. Moreover, the political, social and economic institutions also play important roles in the overall changes of the environment.

The poverty environment linkage has often been mentioned in the sustainable development literature. Malthus was the first to formulate a model on the inter-linkage between population growth and the resource constraints. As a result of rapid population growth, poverty increases and it also induces changes in cropping pattern and extension of cultivation to fragile marginal lands, where the yield is very low, that further impoverishes farmers. 
Ehrlich (1968), Ehrlich and Ehrlich (1990), Mink (1993), Subedi (1997) viewed that environmental deterioration is the direct consequence of population growth.

With growing population and unsustainable consumption patterns of the poorer and their life-styles, the natural resource base of the region including forest has been shrinking and environmental conditions are also deteriorating rapidly. The degradation of forest cover contributes to poverty through worsened health and by constraining the productivity of those resources upon which the poor rely, and poverty restricts capacity of poor to acting in ways, which are not suitable for environment (Neena, 2000). Gill (1999) recognised the deteriorating impact of growing human population on the environmental condition and the resulting fragile environment of Jammu and Kashmir. He opined to contain the population growth that can sustain there without causing undue stress and damage to the physical environment. Sustainable development, thus, is not just about protecting the environment but using our natural resources in the best possible way to eliminate poverty and improve quality of life (Aluko, 2004). These interests raised growing awareness of and fear about environmental degradation effected by the increasing pressures on resource due to population growth and increasing access to resources. Despite this growing awareness, it is only in recent times that concerted attempts are being made to address the problems resulting from environmentally deleterious and unequal development. These efforts require a multidisciplinary approach to understand the ways in which environmental degradation has contributed to the entrenchment of poverty especially in the state of Meghalaya.

Forests meet essential and indispensable needs of the rural population in the form of small timber, fuel, fodder, grazing, and a variety of minor forest produce such as grass, fencing material, bark, fibre, edible flowers and roots, gum and honey, etc. In rural areas, forests even supply food and shelter to the people as well as animal population. Forests also yield a variety of produce of commercial and industrial importance such as timber for buildings, pit props and supports for mining, raw material for forest-based industries like pulp and paper, plywood and boards, rayon, matches, shellac, medicinal plants, and essential oils (Chauhan \& Chuahan, 1998). But to a large extent the exploitation of forest resources in Meghalaya has failed to meaningfully alleviate the poverty of most of its population. The exploitation of the resources in many cases is uncontrolled and due to its very nature of open access or extent of rural poverty is unsustainable.

About 80 per cent of the population in the state of Meghalaya, India still lives in rural areas and agriculture is their main occupation. The people here constantly look for additional land for expanding their cultivation to support the increasing population as well as to improve their economy. In this process, people have been extending cultivation even to the steep hill slopes and clearing forest, raising tendency of soil erosion and affecting the environment. Net-cropped area has increased from 174 thousand hectare in 1976-77 to 219 thousand hectare in 2003-04. Also pressure on forestland increased due to rising number of families under shifting cultivation (Lyngkhoi, 2007). Moreover, there has been increasing demand for timber and non-timber forest products, which is clear from the rising aggregate outputs from the forest in Meghalaya (Lyngkhoi, op cit). Apart from cutting and clearing of forests for agriculture, a large amount of trees have been cut annually for fuel-wood, as firewood is the major source of energy especially in these rural areas.

The objective of this paper is to unfold the nature of dependence on forest and factors affecting degradation of forest in Meghalaya in an interlinking fashion. In the next section a brief review of some available earlier studies on such linkages has been done. Thereafter methodology of the study is described, which is followed by observation and analysis. The concluding remarks are given in the last section.

\section{A Brief Review of Some Earlier Studies on Linkages}

A series of writings since 1960s by Ehrlich (1968), Meadows et al. (1972), Ehrlich and Ehrlich (1990) etc., predicted (in Malthus's line, 1798) that the world would be falling short of critical natural resources after some time if population continues to grow. They argued that if the existing patterns of population growth and resource use continued, it would lead to environmental break down and economic collapse. Even the renewable natural resources like forest, fishery can be exhausted if the population exceeds the carrying capacity and thus rate of extraction is higher than the rate of regeneration. Therefore the Club of Rome stressed on maintaining a balance between the population growth and exploitation of resources for the maintenance of ecological balance and sustainable development of the economies.

Southgate (1988) as well as Ives and Messerli (1988) also cited population growth as the prime contributor to unsustainable deforestation in tropical Africa and the Amazon basin, through the expansion of agriculture and other subsistence activities. Dreze and Sen (1989) have also identified the incidence of poverty and the population growth as the principal reason for the degradation of resources. Joshi (1990) also argued that poverty and population growth (over 2 per cent per year) has affected the economic growth and development of the state 
of Meghalaya. Sen (1994) mentioned that the growth of population is the cause of several problems such as it intensifies food problem, reduces the quality of life of the people and also the happiness of the human race. Dasgupta (1994) also identified the degradation of forest that affects the environment and the resources available for economic development. The main causes of forest degradation are the institutional fashion and poverty. He argued that when population size is higher relatively to the resources available, the more urgent is needed to control the growth of population. At the local level, the combination of poverty and rapid growth of population is often cited as contributing to environmental degradation -for example, rising population pressure leads to farming to hill sides and other marginal areas causing more soil erosion or heavy cutting of forests for fuel, etc. (Birdsall, 1994). Also the small local externality provides an explanation for lack of collective action among local villagers to regulate forest use. The argument for external policy interventions thus depends on the significance of associated non-local externalities related to ecological effects of Himalayan forest degradation and thus Baland et al. (2006) suggested for LPG subsidy to reduce fuel-wood collection and damage to the forest in Himalayan region.

On the other hand, free market economists (the neoclassical) and Julian Simon (1981, 1996), Simon and Myers (1994), Johnson (2000) etc were of the opinion that population growth is not a danger, but a benefit. The world is not running at the risk of shortage of resources. Population growth in many ways helps economic development and better management of resources through their effort and improving knowledge, innovation. Despite huge population growth in the last century the level of well-being has increased manifold and that has been mainly due to the advancement of technology. People of this line argued on the ground of long term absence of catastrophe, major famines, rising average food supply, standard of living, declining mortality, and etc.

These arguments however contradicted by the rising pollution level in many parts of the world, global worming, acid rain, ozone layer depletion, declining forest resources, rising mortality due to lack of safe drinking water, falling long term land productivity, loss of biodiversity in the second half of $20^{\text {th }}$ Century. Here it may be noted that growth of population; when total population is well below the carrying capacity, normally helps better utilisation of resources with given technology and other parameters. If it crosses that limit, it would increase pressure on and thus depletion of resources. Advancement of technology enhances the scope for use of any resource, its productivity but there is uncertainty about the pace and uniformity of its regeneration. Degradation of such resources also varies with the variation in consumption basket that changes along with the changes in living standard and also adjusted by the people with technological invention and innovation (De, op. cit).

Bhagat and Hassan (1994) have shown that the changes in major environmental parameters and degradation of resources in the world during the last Century especially after 1950 was mainly due to the rapid growth of consumption of fossil fuel, industrial production and the growth of the economy, which have been much higher than the rate of growth of population. Therefore, the degradation of natural resources is not only due to the growth of population, but also due to the rapid growth of consumption of resources coupled with the advancement of technology and the later one is much more important than the former one (Macneill, 1989). The rise in per capita consumption of such resources in North America and Western Europe have been much higher than that of other parts of the world, though the rate of population growth was comparatively lower in North America and Western Europe.

Therefore population may be one of the reasons but not the only reasons for the degradation of forest. Ownership pattern may be the other reason. If the resource whether forest or any other is a common resource it will be prone to over-utilisation and hence subject to rapid degradation (Hardin, 1968). Though a major part of forest in Meghalaya is under the community ownership, in most cases there is open access.

Using panel data at the cross-country level and using regression analysis, Cropper and Griffiths (1994) reported that economic growth would not necessarily solve the problem of degradation of forest. Deforestation in developing countries are also due to market failure arises out of undefined property right, zero private cost of deforestation and as most of the poor people has no property right they do not have the incentive to make efficient use of forest land. But higher population growth leads to higher deforestation and thus in their opinion, controlling population growth is the best way to reduce the rate of deforestation.

Though poorer are often blamed for the degradation of the forest, actually they are not always responsible for that, as in many cases they do not have even proper access due to lack of property right. Also because of their indigenous knowledge and for survival, sometimes they are found to better manage and invest in such resources. It is rather the non-poor who has better access to such resources; damage much of the forest resource. The rich overexploit the forest to make profit whereas the poorer are highly affected due to such degradation (World Bank, $1987 \&$ 1988). Boyce (1994) also argued that it is not poverty but a combination of greed, power and wealth that 
causes environmental degradation in many developing countries. Some studies found logging as the principal activity responsible for unsustainable deforestation in many parts of Asia, Central Africa and South America (Somanathan, 1991; Anderson, 1989; Repetto, 1990; Cropper \& Griffiths, 1994). During 1980s also in Meghalaya to a certain extent, due to attractive benefit in the logging industries many of the community forests were privatised that had been harvested unsustainably.

Also there are studies that show that agricultural and pastoral encroachment has been the primary forces behind unsustainable deforestation and logging has been the catalyst. The infrastructure (road etc) developed due to the expansion of logging opened up forestlands for agricultural and pastoral activities that intensified unsustainable deforestation activities in Amazon basin (Goodland, 1991). Westby (1987), Cruz and Gills (1990) argue that shifting cultivators, agricultural and pastoral encroachment in the wake of logging trails were the major causes of deforestation. Jaganathan (1989) highlighted that market were the main factors causing deforestation in Indonesia. There logging activities were followed by conversion of such land to estates and mixed gardens. Of course poorer were involved in unsustainable activities on such logged lands after being abandoned by previous landlords.

FAO (1993) study also concluded that agricultural expansion driven primarily by population pressures was the principal cause for tropical deforestation in the past. Population pressure as well as government policies, which provided incentives for people to move into these areas contributed to the conversion of large tracts of forestlands into permanent agricultural lands. Also FAO (2005) study shows that the highest rate of deforestation in South America especially in Brazil in the world during 2000-2005 was due to the expansion of soybean plantations and cattle ranches. During the same period the second largest net loss in forests were observed in Africa, particularly in Nigeria and Sudan, which was largely due to the subsistence activities.

Using panel data on degradation of forest, incidence of poverty and level as well as variation in per capita SDP, De (2006) has found a significantly positive correlation between income variation and degradation. Also a positive relation is observed in his study between reduction in poverty and degradation of forest. EKC principle however says that the degradation first increase with the rise in income (i.e., in the early stage of development) and after reaching a peak level it declines with further development (Grossman \& Krueger, 1995). He opined that the states of North East India were still low developed having lower per capita income than the national average and hence, they were on the rising phase of EKC. Moreover, whatever poverty reduction had taken place it was at the cost of forest resources, which were easily accessible by the people.

Kuri (2005) has examined the dependence of people on the forest resources in the villages of Arunachal Pradesh and found that almost one-fourth of family income of the poor households comes from common forests resources. The rapid growth of population in the North East India is also partly due to the influx of people from the neighbouring countries, Bangladesh and Nepal and those immigrants in many cases are responsible for the damage of forest cover (Singh, 1987). The rate of growth and size of population in the states of North Eastern India has influence on environment, natural resources and existing system of food productions. As a result of this, the region is experiencing depletion of flora, fauna and soil, fragmentation of cultivated land, rise in import of food grains from other regions and some socio-economic and cultural problems (Husain, 1994).

The demand for timbers, fuel-wood and other commercial uses of forests continued to rise rapidly with fast population growth and causing adverse ecological change and depletion of forest in Meghalaya (Lamin, 1995). In rural areas with large number of population, there is always a tendency to over-exploit the supply of natural resources. Exploitation of forest resources can be attributed to the commercial logging and cultivation purposes, which consequently led to the deforestation and soil erosion (Sanchez, 1998). Datta (2000) and Dutta (2000) also blamed high rate of growth of population, lack of planning and uneconomic use of land for shifting cultivation for the loss of forest cover in vast areas of Meghalaya.

\section{Materials and Methods}

Secondary data (collected from Census Report, Directorate of Statistics, Govt. of Meghalaya, and Statistical Handbook) is used to examine the Karl Pearson's simple correlation between inter-district variation in population growth, density of population, rural literacy rate, income from forest and degradation of forest during the decade of 1990s. As data on all the variables are not available for long period of time as well as for all the districts of Meghalaya, inter-district comparison regression analysis cannot be performed. Therefore, through two-way correlation table (as mentioned earlier) the pattern of relationship among inter-district variation in population growth, rural poverty, changes in contribution of forestry to Net District Domestic Product (NDDP), changes in net earnings from the forest, variation in literacy rate etc is explained. From the correlations among the variables, we tried to find out the dynamic linkage if exists and its nature in the state of Meghalaya. But, as 
the district-wise data on over time changes in poverty is not available and hence correlating changes in poverty with that of forest or population is not possible; we took recourse to primary data to better analyse the inter-linkages among those variables.

As there was lack of data on exact poverty and the nature of dependence of people on forest, primary data have been collected during April-June 2006, from four sample villages in Meghalaya and from the observations on socio-economic characteristics of the sample households and their utilisation of forest resources we tried to unearth the linkages.

Four villages have been selected purposively (two from East Khasi Hills, one from West Khasi Hills and one bordering East and West Khasi Hills) after having a preliminary idea about their locations, characteristics and level of degradation of the forest resource, distance from their nearest towns and business centres, communication facilities and socio-economic condition of the people. Also, the requirement of time, accessibility and cost for the collection of data has been taken into consideration in this regard. These villages are Mawtawar, Laitjem, Sohïong and Mawlangkhar.

Mawtawar and Laitjem are located in Mylliem Community and Rural Development Block and Sohïong in Mawphlang Community and Rural Development Block of the East Khasi Hills district. Whereas, Mawlangkhar belongs to the erstwhile Nongstoiñ (and now to Mawthadraishan) Community and Rural Development Block of West Khasi Hills district.

Sohïong and Mawlangkhar are situated far away from their nearest towns, approximately 30 and $20 \mathrm{KM}$ away from Shillong and Nongstoiñ respectively. Mawtawar and Laitjem are within 5 and $12 \mathrm{KM}$ from their nearest town, Shillong. That means two villages are located nearer to their nearest towns (within $15 \mathrm{KM}$ ) and two are far away from their nearest towns (more than $15 \mathrm{KM}$ ). Presence or absence of timber industries in and around the village is also taken into consideration while choosing the villages. There is only one saw-mill now operating at Mawtawar. Earlier there were five at Laitjem of which now, only three are in operation and at Sohïong earlier there were five and only two are actively running and there is no timber industry at Mawlangkhar though earlier there was one.

From each village, 40 families have been selected by simple random sampling without replacements i.e., in total 160 families have been chosen as sample units. From each family, information on their social and economic background especially family size and composition, level of education, land holding, occupation, monthly income, method of cultivation (if farmer), monthly consumption items, housing pattern and materials used in housing, land holding, number of cattle owned, materials (food, non food, housing and marketable items) collected from the neighbouring forests have been gathered. Also we have taken note of the nature of degradation of forests in all those four villages. From there we tried to find out the reasons for differences in dependence of people on the forest and the difference in level of degradation. From the personal experience, we observe that Mawtawar and Sohïong recorded very high degradation of forests during past decade. Most part of the primary forests in these two villages have been disappeared because of both subsistence and commercial activities, and still now it is continued as these two villages are nearer to business centres and incidence of poverty is also high (though relatively better than the other two villages) despite closer to urban area. Influx of population from the remote villages further compounded the problem. Because of lack of alternative opportunities, education facilities and rising pressure on jhum land, poor people migrate to urban informal sector and settle in the outskirt of the city or stay in the nearby villages from where they can shuttle everyday to their working place. The degradation of forest in the other two villages, Laitjem and Mawlangkhar, are however less as compared to Mawtawar and Sohïong, though they are relatively poorer and there is less availability of substitutes of forest produce like fuel-wood. Agriculture is their main occupation. However, people are also engaged in other occupation and business activities in these villages but on a very minor scale except in Mawtawar.

The socio-economic status of the people is examined through their land holding, ownership of cattle, housing pattern, source of earning and its level. Also dependence on forest is gathered from the items collected and their quantity, proportion of income comes from collection of forest resource, which is again regressed on several explanatory variables like per capita income, educational level, family size, land holding etc to examine the impact of various factors on the dependence on forest resources that helps in understanding the reasons for forest resource degradation in the state and its spatial differences. 


\section{Observation and Analysis}

\subsection{Analysis of Secondary Data}

Changes in poverty (especially rural poverty) are not incorporated in correlation table, as district-wise time series figures are not available. But one point to be noted is that, the state itself is a poverty prone state and changes in Net District Domestic Product or per capita NDDP, which is very low, can be an indicator of economic condition of the people and thus it is considered for the analysis. More per capita NDDP of a district (if distribution does not differ much) implies relatively less poor district and vice versa. Also persistence of jhum cultivation is there that is normally practised by the poor families.

The correlation Table 1 showed that the inter-district variation in growth and density of population were significantly negatively correlated to that of NDDP and per capita NDDP and significantly positively correlated with the variation in contribution of forest to NDDP and degradation of forest. Variation in growth of literacy rate and per capita NDDP are negatively correlated to contribution of forest to NDDP and degradation of forest. These two are also negatively related with the variation in percentage of family under jhum cultivation, and area under jhum cultivation but not significantly. However, positive correlation is observed among the percentage of family and area under jhum cultivation and contribution of forest to NDDP.

Table 1. Two way correlation analyses (using Karl Pearson's method)

\begin{tabular}{|c|c|c|c|c|c|c|c|c|}
\hline & $\begin{array}{l}\text { Population } \\
\text { Growth }\end{array}$ & $\begin{array}{l}\text { Rural } \\
\text { Literacy } \\
\text { Rate }\end{array}$ & $\begin{array}{l}\text { Growth of } \\
\text { Population } \\
\text { Density }\end{array}$ & $\begin{array}{l}\text { Growth } \\
\text { of } \\
\text { NDDP }\end{array}$ & $\begin{array}{l}\text { Growth } \\
\text { of Per } \\
\text { capita } \\
\text { NDDP }\end{array}$ & $\begin{array}{c}\text { Changes in } \\
\text { Contribution } \\
\text { of Forest to } \\
\text { NDDP }\end{array}$ & $\begin{array}{l}\text { Percentage } \\
\text { of Family } \\
\text { in Jhum } \\
\text { Cultivation }\end{array}$ & $\begin{array}{l}\text { Area under } \\
\text { Jhum } \\
\text { Cultivation }\end{array}$ \\
\hline $\begin{array}{l}\text { Population } \\
\text { Growth }\end{array}$ & 1 & & & & & & & \\
\hline $\begin{array}{c}\text { Rural } \\
\text { Literacy } \\
\text { Rate }\end{array}$ & 0.146 & 1 & & & & & & \\
\hline $\begin{array}{l}\text { Growth of } \\
\text { Population } \\
\text { Density }\end{array}$ & -- & -- & 1 & & & & & \\
\hline $\begin{array}{l}\text { Growth of } \\
\text { NDDP }\end{array}$ & -0.512 & -- & -0.487 & 1 & & & & \\
\hline $\begin{array}{l}\text { Growth of } \\
\text { Per capita } \\
\text { NDDP }\end{array}$ & -0.774 & 0.30 & -0.715 & & 1 & & & \\
\hline $\begin{array}{l}\text { Changes in } \\
\text { contribution } \\
\text { of Forest to } \\
\text { NDDP }\end{array}$ & 0.5266 & -0.60 & 0.461 & 0.069 & -0.923 & 1 & & \\
\hline $\begin{array}{l}\text { Percentage } \\
\text { of Family in } \\
\text { Jhum } \\
\text { Cultivation }\end{array}$ & -0.107 & -0.306 & -0.09 & 0.43 & -0.28 & 0.453 & 1 & \\
\hline $\begin{array}{l}\text { Area under } \\
\text { Jhum } \\
\text { Cultivation }\end{array}$ & -0.17 & -0.431 & -0.24 & 0.062 & -0.354 & 0.481 & 0.6714 & 1 \\
\hline $\begin{array}{l}\text { Degradation } \\
\text { of Forest } \\
\text { Land }\end{array}$ & 0.411 & -0.265 & 0.298 & -0.31 & -0.511 & 0.461 & -0.52 & -0.0479 \\
\hline
\end{tabular}

Source: Compiled from the data available from secondary sources viz. Census of India, planning commission and directorate of economics and statistics, government of Meghalaya.

The results thus indicate that population growth and rising density significantly and adversely affect and are affected by the growth of NDDP i.e., positively associated with the incidence of poverty if there is resource constraint. Even though other natural resources like minerals are there, majority of which are owned by a few individuals and thus people especially poorer, are more dependent on easily accessible semi-common forests. 
Normally poor people prefer more children for better security and collection from the degraded forest. However, if people become educated, they look for alternative opportunities and stress on forest also declines and hence its share in NDDP as well rate of degradation also declines. But in Meghalaya, the effect of education is not so strong because of presence of chronic poverty. Though inter-district variation in growth of per capita NDDP has significantly negative impact on contribution of forest to total NDDP or degradation of forest (indicating that with economic growth or development, pressure on forest declines), actually growth of per capita NDDP of all the districts are much lower than at all India level (which is also clear from the decline in state level ranking in human development and human poverty index) and hence impact on percentage of family and area under jhum cultivation is not so strong. But when income rises, people become less dependent on forest for food, fodder and other materials and hence degradation is likely to be less. However, if contribution of forest to NDDP rises growth of NDDP will be higher and that is likely to compound degradation.

Percentage of family and area under jhum cultivation are found negatively correlated with variation in degradation of forest. Still now many of the rural families in some districts are dependent on jhum cultivation (due to low income and less alternative opportunities) and still now density of population in those districts is much lower than all India average and other districts (e.g., East Khasi Hills) where less people are dependent on jhum, but due to more density of population per capita availability of land is very less. Therefore the district where relatively less people are engaged in jhum, due to less per capita forestland fallow period is short and hence more degradation is observed (as in East Khasi Hills). But the district with higher percentage of people in jhum, due to relatively more per capita land availability, fallow period is relatively longer and hence recorded comparatively low degradation. Moreover, if people become educated but due to lack of availability or entitlement cannot adopt modern techniques of settled cultivation, they try to judiciously manage the cultivable land. Therefore there is likely to be relatively less degradation of forest. However, rapid population growth in that case may disturb the balancing use of forestland for survival. But given the population growth, the district having better quality of forest and hence larger contribution of forest, would have relatively higher growth of per capita Net Domestic Product.

The flow-chart 1 indicates how population growth (directly or indirectly) affects and is affected by degradation of forest resources. Similarly, it shows how poverty or growth of per capita income affects and is affected by degradation of natural resource like forest and also how population growth affects and is affected by the variation in per capita income. So it explains the nature of relationship among population growth, per-capita income and thus incidence of poverty (where income growth is faster, incidence of poverty is likely to decline) and degradation of forest in Meghalaya (especially during 1990s).

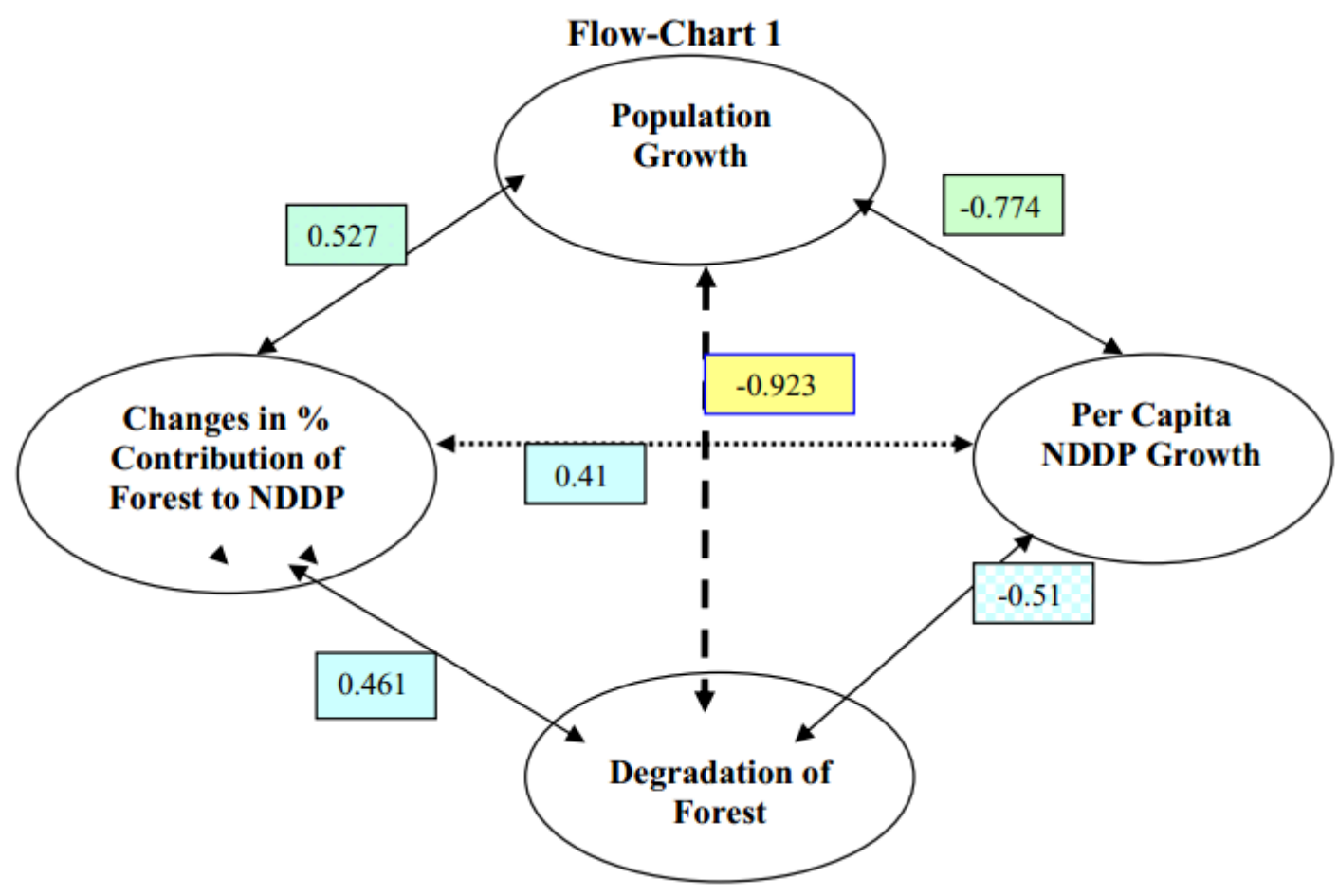


The relationship can be shown as:

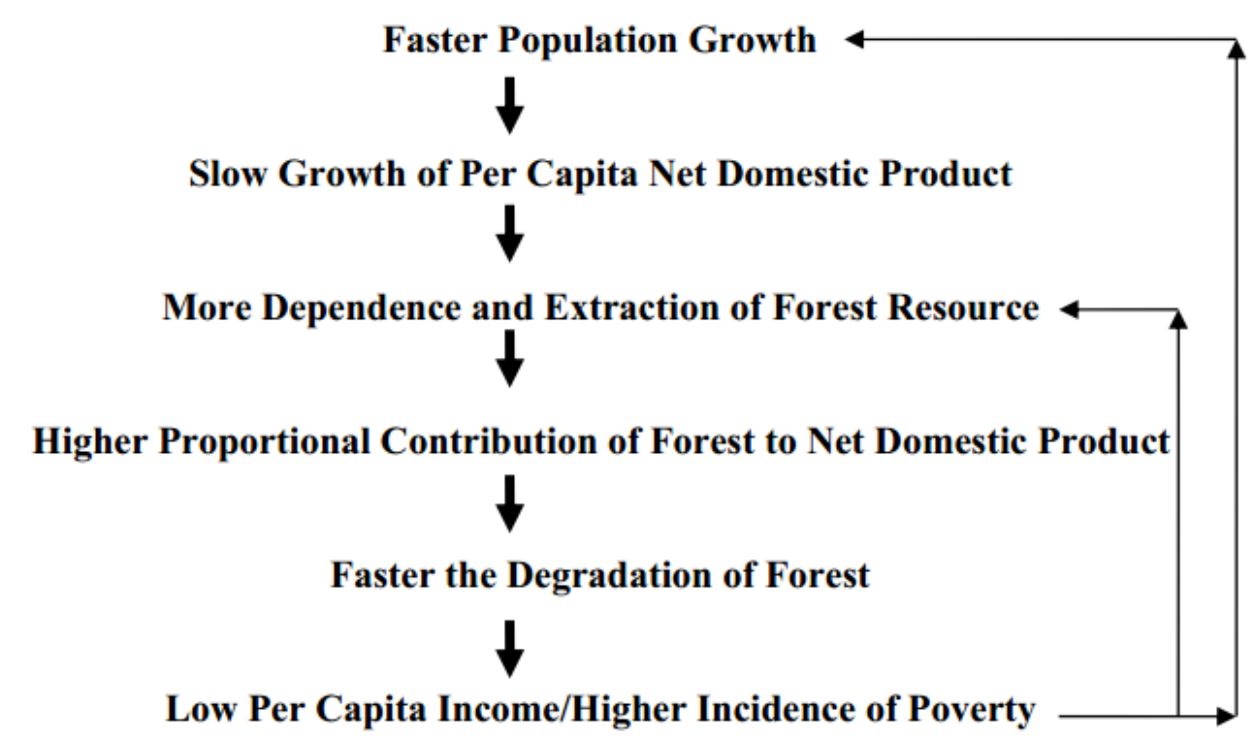

\subsection{Analysis of the Linkage on the Basis of Primary Data}

\subsubsection{Socio-Economic Profile of Sample Villages}

The population, family size, the characteristics of their dwelling houses, literacy rate and educational status of the people, their income, etc are first described in this section. Population and its sex composition as observed from the Census of India 2001 are displayed in Table 2. Total population size of the four sample villages surveyed is 3139, including 1548 males and 1591 females. Average sex ratio is in favour of females in the surveyed villages, which is opposite to that of all India level and Meghalaya as a whole. Laitjem and Mawtawar have sex ratios 1021 and 1070. It is the highest in Sohïong (1134) and lowest in Mawlangkhar (725) respectively.

Table 2. Total population in the sample villages

\begin{tabular}{ccccc}
\hline Village & Persons & Males & Females & Sex Ratio per 1000 Male \\
\hline Laitjem & $1134(36.13)$ & $561(36.24)$ & $573(36.01)$ & 1021 \\
Mawtawar & $1062(33.83)$ & $513(33.14)$ & $549(34.51)$ & 1070 \\
Sohïong & $655(20.87)$ & $307(19.83)$ & $348(21.87)$ & 1134 \\
Mawlangkhar & $288(9.17)$ & $167(10.78)$ & $121(7.61)$ & 725 \\
Total & $3139(100.00)$ & $1548(100.00)$ & $1591(100.00)$ & 1028
\end{tabular}

Source: Census of India, 2001.

Note: Figures in brackets indicate percentages to total population of the four sample villages.

The family size in the sample villages as obtained from the survey data ranged from around 6 to 8.35 persons per family (Table 3). The number of males and females also comprised of 3 to 5 persons. Also the number of adult and children varies from 3.48 to 4.77 and 2.57 to 3.58 respectively. Sex ratio among the adult and child category also follows similar pattern as that of total population. Among the four villages, Mawtawar has the lowest average family size and number of children per family reflecting the influence of urban contact, educational facilities, and health care hence relatively better human development. On the other hand Mawlangkhar has the highest family size. 
Table 3. Family size in the sample villages

\begin{tabular}{cccccc}
\hline Village & Persons & Males & Females & Adult & Children \\
\hline Laitjem & 6.82 & 3.30 & 3.55 & 3.62 & 3.20 \\
Mawtawar & 6.07 & 3.13 & 3.00 & 3.48 & 2.57 \\
Sohïong & 7.30 & 3.70 & 3.60 & 3.65 & 3.65 \\
Mawlangkhar & 8.35 & 4.82 & 4.52 & 4.77 & 3.58
\end{tabular}

Source: Compiled from the field survey.

Mawtawar is comparatively more advanced among all the four villages in terms of educational achievement as described in Table 4. Among all the members of forty families in Mawtawar 52.50 per cent are literate, of which 40 per cent being just literate, 5 per cent secondary passed but less than graduate, and 7.5 per cent graduates and above. It is followed by Laitjem with 32.50 per cent of population literate, of which, 5 per cent secondary passed, but less than even high secondary, and only 2.5 per cent graduates. Mawlangkhar records 30 per cent literacy rate, of which merely 2.5 per cent secondary passed, while Sohïong ranked last with just 10.00 per cent literate. The fact is that Mawtawar has the benefit of urban influence, while Sohïong and Mawlangkhar are far away from the urban area and no urban influence is observed.

Table 4. Literacy rate and education in the sample villages (in \%)

\begin{tabular}{ccccccc}
\hline Village & Illiterate & $\begin{array}{c}\text { Literate but }< \\
\text { Secondary }\end{array}$ & $\begin{array}{c}\text { Secondary } \\
\text { but }<\text { H.S. }\end{array}$ & $\begin{array}{c}\text { H.S. but } \\
<\text { Graduate }\end{array}$ & $\begin{array}{c}\text { Graduate and } \\
\text { Above }\end{array}$ & Total \\
\hline Laitjem & 67.50 & 25.00 & 5.00 & 0.00 & 2.50 & 100 \\
Mawtawar & 47.50 & 40.00 & 2.50 & 2.50 & 7.50 & 100 \\
Sohïng & 90.00 & 10.00 & 0.00 & 0.00 & 0.00 & 100 \\
Mawlangkhar & 70.00 & 27.50 & 2.50 & 0.00 & 0.00 & 100 \\
\hline
\end{tabular}

Source: Compiled from the field survey.

The incidence of poverty as estimated by using the standard of Rs 327.56 per capita monthly income as poverty line for the sample villages is shown in Table 5. Most of the families in Mawlangkhar (97.50 per cent) are observed to be poor, followed by Laitjem ( 80 per cent) and Sohïong ( 75 per cent). Only 32.5 per cent of families in Mawtawar are poor. Despite variations in the level of education, all these four villages are suffering from poverty, which is chronic in all but Mawtawar.

Table 5. Distribution of poor and non-poor in the sample villages (\%)

\begin{tabular}{ccc}
\hline Village & Poor & Non-Poor \\
\hline Laitjem & 80.00 & 20.00 \\
Mawtawar & 32.50 & 67.50 \\
Sohïong & 75.00 & 25.00 \\
Mawlangkhar & 97.50 & 2.50
\end{tabular}

Source: Compiled from the field survey.

The average monthly income and expenditure of the households in the sample villages are very low compared to national average as shown in Table 6. The average monthly family income varies from Rs 1870.25 in Mawlangkhar to Rs 3743.75 in Mawtawar. Similarly, monthly family expenditure is the lowest in Laitjem, Rs 1702.40 and it is the maximum in Mawlangkhar, Rs 1867.80. One may be sceptical about the highest family expenditure of the families of Mawlangkhar where about 97.5 per cent of the families are poor. Actually, in the 
estimation of total family income the imputed values of items collected from the forest either for consumption or building cottages or fuel-wood or for sale are considered. In Mawlangkhar, family size is larger than other village and most of the members go for collecting forest resources primarily for their subsistence consumption. Though in Mawlangkhar these items are mostly not traded the average value of those items in other markets where these are traded are being taken into account. Similarly for the other villages whether the items are traded or consumed are also considered. Moreover, in the expenditure, values of the items collected and consumed are also incorporated. In Mawlangkhar the harvesting and hunting in the forest is carried out mainly for subsistence where as the in Mawtawar extracted resource is used for both subsistence and commercial purposes. However, in the expenditure we have considered only the general consumption expenditure whether the items are collected from forest or not. But the expenditure on fixed asset like housing etc that is received as aid is not considered.

Table 6. Average monthly family income and expenditure of the sample households (Rs)

\begin{tabular}{cccccc}
\hline Village & $\begin{array}{c}\text { Family } \\
\text { Income }\end{array}$ & $\begin{array}{c}\text { Family } \\
\text { Expenditure }\end{array}$ & $\begin{array}{c}\text { Per Capita } \\
\text { Income }\end{array}$ & $\begin{array}{c}\text { Per Capita } \\
\text { Expenditure }\end{array}$ & $\begin{array}{c}\text { Coeff. of Var. } \\
\text { in family income }\end{array}$ \\
\hline Laitjem & 2126.50 & 1702.40 & 311.8 & 249.62 & 99.11 \\
Mawtawar & 3743.75 & 1753.60 & 616.76 & 288.90 & 95.79 \\
Sohïong & 2446.75 & 1831.80 & 335.17 & 250.93 & 87.99 \\
Mawlangkhar & 1870.25 & 1867.80 & 223.98 & 223.69 & 48.51 \\
\hline
\end{tabular}

Source: Compiled from the field survey.

Though average family expenditure is the highest, monthly expenditure per capita is the lowest in Mawlangkhar (Rs 223.69), while highest in Mawtawar (Rs 288.9). This is because of the larger family size in Mawlangkhar compared to that of Mawtawar. Moreover, coefficient of variation in income is the highest in Laitjem (99.11) and lowest in Mawlangkhar (48.51). The values for Mawtawar and Sohiong are about 96 and 88 per cent. So, higher income area has a tendency to be associated with greater inequality in the distribution of income.

Table 7. Distribution of families according to the job status of head of the households in the surveyed villages (\%)

\begin{tabular}{cccccc}
\hline Village & Service & Agricultural Labourer & Cultivator & Business & Other \\
\hline Laitjem & 5.00 & 5.00 & 35.00 & 10.00 & 45.00 \\
Mawtawar & 25.00 & 12.50 & 15.00 & 7.50 & 40.00 \\
Sohïong & 0.00 & 12.50 & 75.00 & 0.00 & 12.50 \\
Mawlangkhar & 0.00 & 7.50 & 57.50 & 0.00 & 35.00 \\
\hline
\end{tabular}

Source: Compiled from the field survey.

Table 7 reveals that in Mawlangkhar and Sohïong, number of head of the households in the government service and business activities are nil. Most of them are engaged in the cultivation ( 75 per cent) and equal 12.5 per cent are agricultural labourer and engaged in other economic activities respectively in Sohiong. In Mawlangkhar, 57 and 35 per cent are in cultivation and other activities (carpenter, mason or other informal occupation) respectively and the rest are agricultural labourer. 25 and 5 per cent respectively in Mawtawar and Laitjem are in service while 40 and 45 per cent head of the families in those two villages are in other activities. Also 12.50 and 7.5 per cent are working as agricultural labourers and in business in Mawtawar. In Laitjem, cultivators are 35 per cent and 10 per cent are in business and only 5 per cent are agricultural labourer.

Most of the people in the sample families live in Kachha houses except in Mawtawar, where about 22.5 per cent of the families live in pucca houses (Table 8). For the construction of Kachha houses major portion of the materials (timber, bamboo, leaves etc) are collected from the nearby forest. Those who are relatively better off in terms of job status as well as income and do not collect themselves (either for status and position in the society or higher opportunity cost), purchase those items from others. 
Table 8. Distribution of families according to the character of dwelling houses (\%)

\begin{tabular}{cccc}
\hline Village & Kachha & Pucca & Total \\
\hline Laitjem & 92.50 & 7.50 & 100.00 \\
Mawtawar & 77.50 & 22.50 & 100.00 \\
Sohïong & 97.50 & 2.50 & 100.00 \\
Mawlangkhar & 100.00 & 0.00 & 100.00
\end{tabular}

Source: Compiled from the field survey.

Table 9 shows that fuel-wood is the main items that the people of these sample villages are using for their cooking purposes. Only a few of the people are using charcoal, LPG and other cooking materials like kerosene and electricity. Only 2.5 per cent of the families in Mawtawar, which is nearer to town, are using LPG gas and 12.5 per cent are using other cooking materials while 17.5 per cent use charcoal. It indicates that some families in Mawtawar are using combination of two/three types of fuel. In Sohïong and Mawlangkhar, 27.5 and 12.5 per cent of the families use charcoal along with fuel-wood. The figure is only 5 per cent in Laitjem. Therefore, forest is the main source of fuel or energy especially in the rural areas. In the more interior areas even the richer are compelled to use litters and fuel-wood as other sources of fuel are not available.

Table 9. Distribution of families according to the use of fuel for cooking in the sample villages (\%)

\begin{tabular}{ccccc}
\hline Village & Fuelwood & LPG & Charcoal & Other \\
\hline Laitjem & 100.00 & 0.00 & 5.00 & 2.50 \\
Mawtawar & 95.00 & 2.50 & 17.50 & 12.50 \\
Sohïong & 100.00 & 0.00 & 27.50 & 0.00 \\
Mawlangkhar & 100.00 & 0.00 & 12.50 & 0.00 \\
\hline
\end{tabular}

Source: Compiled from the field survey.

Table 10 revealed that almost all the families in the village Mawlangkhar collect fuel-wood. But in other three villages the figure varies from 45 to 62.5 per cent though most of the families in those villages also use fuel-wood or charcoal (as seen in Table 9). It indicates that many of the families in those villages purchase fuel-wood, charcoal (of course that comes from the nearby forest) from the market and many people earn by selling those. Another reason may be that the family size is small in Mawtawar and hence they have less manpower to collect fuel-wood from the relatively more degraded area and some of them have relatively better job opportunities and hence opportunity cost of collecting fuel-wood is more.

Table 10. Distribution of families in the sample villages collecting items of daily need from the forests (\%)

\begin{tabular}{ccccccc}
\hline Village & Fruit & Leaves & Fuelwood & Timber & Bamboo & Grass \\
\hline Laitjem & 0.00 & 5.00 & 50.00 & 0.00 & 0.00 & 0.00 \\
Mawtawar & 0.00 & 0.00 & 45.00 & 0.00 & 5.00 & 5.00 \\
Sohïong & 5.00 & 35.00 & 62.50 & 5.00 & 5.00 & 25.00 \\
Mawlangkhar & 15.00 & 52.50 & 97.50 & 20.00 & 10.00 & 60.00 \\
Total & 5.00 & 23.12 & 63.75 & 6.25 & 5.00 & 22.50 \\
\hline
\end{tabular}

Source: Compiled from the field survey.

Many of the people in the sample villages used to collect some other necessary items from the forests for meeting a part of their daily needs such as fruits, leaves, timber, bamboo, grass, etc. The table shows that 15 per cent of families of Mawlangkhar and 5 per cent of Sohïng used to collect fruits from the nearby forests. Also 52.00 and 35.00 per cent used to collect leaves, 97.50 and 62.50 per cent timber, 10.00 and 5.00 per cent bamboo 
and 60.00 and 25.00 per cent grass respectively in those two villages. On the other hand, families of Laitjem and Mawtawar used to collect mainly fuel-wood $(50.00 \%$ and $45.00 \%$ respectively) and only very few of them collect other items. Whereas the over all collection of fuel-wood and timber is done by the 63.75 and 6.25 per cent of families in the four villages. Apart from those items, people of rural Meghalaya also collect wild roots, stems, bamboo shoots, seeds for consumption and some people also go for hunting. However, wild biodiversity has been declining due to loss of dense forest. Though time series data is not available on those aspects one can safely argue that the availability of those materials must be declining with the degradation of their host, which is forest.

Table 11. Monthly average income, expenditure and per capita income of the households that collect materials from the Forests (in Rs)

\begin{tabular}{ccccccc}
\hline Village & $\begin{array}{c}\text { No. } \\
\text { of } \mathrm{H} \\
\mathrm{H}\end{array}$ & Population & $\begin{array}{c}\text { Average } \\
\text { family Income }\end{array}$ & $\begin{array}{c}\text { Average } \\
\text { Family } \\
\text { Expenditure }\end{array}$ & $\begin{array}{c}\text { Per Capita } \\
\text { Income }\end{array}$ & $\begin{array}{c}\text { Per Capita } \\
\text { Expenditure }\end{array}$ \\
\hline Laitjem & 21 & 156 & 1717.29 & 1711.61 & 231.17 & 230.41 \\
Mawtawar & 17 & 106 & 2955.88 & 1476.00 & 474.06 & 236.72 \\
Sohïong & 25 & 200 & 2909.84 & 2026.88 & 363.73 & 253.36 \\
Mawlangkhar & 39 & 329 & 1840.54 & 1834.80 & 218.18 & 217.50 \\
\hline
\end{tabular}

Source: Compiled from the field survey, Note: HH means household.

Table 11 shows the average family and per capita income and expenditure of the households that used to collect materials from the forests. In Laitjem, out of 40 households, 21 households who collect material from forest have average family income of Rs. 1717.29. The figures for 17, 25 and 39 families of Mawtawar, Sohiong and Mawlangkhar are Rs. 2955.88, Rs. 2909.84 and Rs.1840.54. The per capita income of those families in the respective villages is Rs. $231.17,474.06,363.73$ and 218.18 respectively. Similarly average family expenditure of those families varies from Rs 1711.61 to Rs. 2026.88. Per capita expenditures however are Rs. 230.41, 236.72, 253.36 and Rs. 217.50. Except in Sohiong in other villages' per capita income and expenditure of the families who collect materials from forest are lower than those, who do not collect anything from forest. It is observed when we compare it with the results for all families as shown in table-6. It indicates that the poorer collect more for their subsistence from the forest than the relatively better off families.

In Sohiong actually 75 per cent of the families are cultivator and also many of them harvest their clan forest primarily timber, bamboo along with other items, which are sold in the timber industries located in their village. Whereas in other villages especially in Laitjem and Mawlangkhar, people who do not have sufficient alternative opportunities mainly harvest forest for fuel-wood, grass, leaves for their subsistence. In Mawtawar however the earning of the people who collect material from forest is more than those of other villages though they collect mainly fuel-wood and a few collect bamboos. This is because the families who collect forest resource (it is their subsidiary income) in Mawtawar simultaneously earn from other sources as some other family members are engaged in relatively better (mainly informal) opportunities in the nearby town. Also they get better price of the forest products in town.

Table 12. Number of cattle in the sample villages (in hundred)

\begin{tabular}{cccccc}
\hline Village & Cow & Goat & Sheep & Pig & Total \\
\hline Laitjem & 0 & 0 & 0 & 23 & 23 \\
Mawtawar & 0 & 0 & 0 & 0 & 0 \\
Sohïong & 53 & 24 & 7 & 28 & 112 \\
Mawlangkhar & 143 & 23 & 13 & 33 & 212 \\
Total & 196 & 47 & 20 & 83 & 347 \\
\hline
\end{tabular}

Source: Compiled from the field survey. 
Owning of cattle by the sample households is displayed in Table 12 . The total number of cattle recorded by the people of the sample villages was 347, (196 cows, 47 goats, 20 sheep and 83 pigs). Mawtawar is the only village that has been found without any cattle rearing. Moreover, people of this village are relatively rich and forest in Mawtawar is already degraded compared to other villages and so people will have to go far away for grazing their cattle. But the family size here is smaller and number of children who generally performs this task is less in number and most of the available children are in education and thus very less time is devoted to such activities. Also the opportunity cost of grazing cattle by the high collar job holders are more and hence there is less incentive in rearing cattle. In Laitjem only 23 pigs are recorded. However, maximum number of cattle is reared in Mawlangkhar and followed by Sohïong, which is an indication of deep dependence on neighbouring forest resources of Mawlangkhar.

Table 13. Distribution of family members of the cultivator headed families in the sample villages (\%)

\begin{tabular}{ccccc}
\hline Village & Permanent (1) & Shifting (2) & Both (1+2) & None-of these \\
\hline Laitjem & 20.00 & 17.50 & 22.50 & 40.00 \\
Mawtawar & 17.50 & 5.00 & 0.00 & 77.50 \\
Sohïong & 37.50 & 17.50 & 30.00 & 15.00 \\
Mawlangkhar & 55.00 & 0.00 & 35.00 & 10.00 \\
\hline
\end{tabular}

Source: Compiled from the field survey.

Earlier we had seen that maximum families in Sohiong and Mawlangkhar are cultivators (Table 7). Both permanent and shifting cultivation have been practised by the villagers, which is shown in Table 13. Rice is grown in the field especially by those practising permanent cultivation, whereas in shifting cultivation, besides the main crops of rice and maize, other crops such as vegetables, millets, potatoes, sweet potatoes, pulses, chillies, ginger, cabbage, cauliflower and many others are also grown. Table 13 also shows that 30 per cent and 35 per cent of the cultivator headed families in Sohiong and Mawlangkhar respectively follow both shifting and settled cultivation. Now many are following permanent cultivation due to lack of forest resources and that is compounded by the rising population though the productivity is still lower because of non-application of modern inputs. The non-of these, here indicate the children or very old people of the cultivator headed families and to those who are engaged in raising orchids, other plantations or in small business etc.

Table 14. Distribution of families according to ownership of land (in \%)

\begin{tabular}{cccccc}
\hline Village & Own Land & $\begin{array}{c}\text { Community } \\
\text { Land }\end{array}$ & $\begin{array}{c}\text { Other Private } \\
\text { Land }\end{array}$ & $\begin{array}{c}\text { Own \& Other } \\
\text { Private Land Both }\end{array}$ & Other Land \\
\hline Laitjem & 19.44 & 8.33 & 58.33 & 2.78 & 11.11 \\
Mawtawar & 2.78 & 22.22 & 69.44 & 5.56 & 00.00 \\
Sohïong & 16.22 & 32.43 & 48.65 & 2.70 & 00.00 \\
Mawlangkhar & 32.26 & 00.00 & 54.84 & 12.90 & 00.00 \\
\hline
\end{tabular}

Source: Compiled from the field survey.

In Laitjem, 19.44 per cent of families have their own land for settled cultivation and other purposes and the rest of the people are using community land (8.33\%), other private individual land $(58.33 \%)$ and other land not included in the above category (11.11\%). Only 2.78 per cent family uses both own and other private land. In Mawtawar, only 2.78 per cent of the people own land, 22.22 per cent uses community land and 69.44 per cent enjoys other private land and 5.56 per cent use both types of land. In Sohïong, 16.22 per cent of the inhabitants have their own land and 32.43 per cent depend on the community or clan land and 48.65 per cent encroach to other private individual land, whereas in Mawlangkhar 32.26 per cent of the people are owning land and 54.84 per cent depend on other private land, 12.90 per cent use both and nobody is found to use community land as there is no community land in this village (Table 14). 
Based on the reply by the people of these villages, it is observed that most of the people in Laitjem agree that in-migration has taken place in that village during last 15 years (because it is nearer to town, though it is also a poor village) from interior villages for business, cultivation or joining as daily labourer due to lack of sustenance in their native villages. The crisis in the migrants' original village has been due to population growth and simultaneous fall in availability of forest resource (Table 15). Out-migration of the people in Mawtawar is nil and 100.00 per cent of the people agree that in-migration has been there from interior villages to have opportunities in neighbouring town and other reasons mentioned above. Also 77.50 per cent of the people in Sohïong informed that the people from the village migrated to other parts of the state in search of job and employment opportunities and 85.00 percent of the people in Mawlangkhar are migrated to urban areas and centres for accessing better unskilled job and facilities to improve their standard of living. However, no inmigration has been reported by the respondents of this village. Some people of Sohiong and Mawlangkhar are reluctant to say anything about it. It indicates that the people of Mawlangkhar, who are very poor and due to large family size (hence rising population over time); intensity of dependence on forest increase but income drawn from forest declining and hence people forced to go to other relatively developed or virgin forest areas for the survival.

Table 15. Distribution of families according to their response on migration within last fifteen eYars due to forest related reasons (in Percentage)

\begin{tabular}{ccc}
\hline Village & Out-migration & In-migration \\
\hline Laitjem & 2.50 & 97.50 \\
Mawtawar & 0.00 & 100.00 \\
Sohïong & 77.50 & 12.50 \\
Mawlangkhar & 85.00 & 0.00
\end{tabular}

Source: Compiled from the field survey.

From the comparison of tables we find that people of poorer village earn relatively more from forest. However, people of village adjacent to town or having more timber industries also harvest forest and both for sustenance and commercial activities and hence intensify the process of degradation. Though major fuel source in all the villages is firewood, in the distant village intensity of fuel-wood use is relatively more due to lack of alternative energy resources. For the cultivation or harvesting of forest materials people of all the villages depend both on personal, community and other private land. Government forest land is very less in these areas.

\section{Regression Result}

Here simple linear regression is followed and though education, family size, job status are supposed to be correlated we find no significant correlation among them except between job status and education or family size and income, which is presented in the two-way correlation Table 16. Hence in some equations we exclude job status or consider only average schooling of the adults' only and record changes in parameters but no significant changes in result is observed.

Table 16. Two-way correlation analyses

\begin{tabular}{cccccccc}
\hline & $\begin{array}{c}\text { Average } \\
\text { Schooling }\end{array}$ & $\begin{array}{c}\text { Monthly } \\
\text { Family Income }\end{array}$ & $\begin{array}{c}\text { Distance } \\
\text { from } \\
\text { Town }\end{array}$ & $\begin{array}{c}\text { Land } \\
\text { Ownership }\end{array}$ & $\begin{array}{c}\text { Job } \\
\text { Status }\end{array}$ & $\begin{array}{c}\text { Family } \\
\text { Size }\end{array}$ & $\begin{array}{c}\text { No. of } \\
\text { Saw } \\
\text { Mill }\end{array}$ \\
\hline Average Schooling & 1 & .0508 & -.307 & -.0556 & -.516 & -.1046 & .0057 \\
Monthly Family & & 1 & -.1989 & -.2752 & .0785 & -.539 & -.0709 \\
$\quad$ Income & & & 1 & .0703 & .2669 & .14232 & 00 \\
Distance from Town & & & & 1 & -.0277 & -.017 & .02009 \\
Land Ownership & & & & & 1 & .0905 & -.02913 \\
Job Status & & & & & & 1 & -.01581 \\
Family Size & & & & & & & \\
\hline
\end{tabular}

Source: Compiled from the field survey. 
The result obtained by simple linear regression is presented below:

$$
\begin{aligned}
& \text { 1. } \mathrm{FW}=0.3316-0.078 \text { EDU- } 0.0003 \mathrm{FI}^{*}+.0521 \text { FSIZE }^{*}-0.03125 \mathrm{JOB} \\
& (-.668) \quad(-1.75) \quad(3.76) \quad(-1.077) \\
& +0.1735 \text { LAND* }+0.1833 \text { D* } \\
& \mathrm{R}^{2}=0.281, \mathrm{R}(\text { bar })^{2}=.27, \mathrm{n}=160, \mathrm{df} .=153 \\
& \text { 2. } \mathrm{INF}=0.072+0.0171 \mathrm{EDU}-0.00012 \mathrm{FI}^{*}+0.00502 \mathrm{FSIZE}^{*}-0.009 \mathrm{JOB}^{*} \\
& \begin{array}{lll}
(.822) & (-4.13) \quad(2.03)
\end{array} \\
& \text { (2.03) (-1.75) } \\
& +0.0111 \mathrm{LAND}+0.064 \mathrm{D}^{*} \\
& \underline{\mathrm{R}^{2}=0.32, \mathrm{R}(\mathrm{bar})^{2}=.31, \mathrm{n}=160, \mathrm{df} .=153}
\end{aligned}
$$

\section{Note:}

[Here $\mathrm{FW}=$ Fuel-wood, $\mathrm{INF}=$ percentage of family income earned due to forest resources, EDU=Average Schooling, FI=Monthly Family Income, FSIZE=Family Size, JOB=Job Status, LAND=Land Ownership, D = Distance of Village from the nearest town, $\mathrm{df}$ indicates the degrees of freedom, figures in the parentheses are the $\mathrm{t}$-values. Symbol $*$ and $* *$ indicate that the coefficient is significant at 5 and 10 per cent level of significance respectively\}. [Average schooling index per family is calculated in the following way. First we have assigned values 0 for illiterate, 1 for literate but less than secondary passed, 2 for secondary but less than higher secondary, 3 for higher secondary but less than graduate and 4 for graduate and above. After assigning the values for each individual we added to get aggregate value of each family and then dividing by the family size we estimated average schooling index. Similarly the education index for the adults is constructed. For job status, we have put 1 for service, 2 for agricultural labourer, 3 for cultivator, 4 for business and 5 for others. Normally we assume that more combined job status of families will have a negative impact on degradation. Though service holders have relatively less tendency to degrade but here we observe very few people who belong to that category].

Incorporating the number of sawmills in the villages we find,

3. $\mathrm{INF}=0.12-0.0076 \mathrm{EDU}-0.00012 \mathrm{FI}^{*}+0.005 \mathrm{FSIZE}^{*}-0.0082 \mathrm{JOB}^{*}$

$$
\begin{aligned}
& \begin{array}{llll}
(.38) & (-4.19) \quad(2.024) \quad(-1.714)
\end{array} \\
& +0.011 \text { LAND + 0.0602 D* - } 0.014 \text { SM}^{*} \\
& \text { (.75) (4.81) (-4.94) ; } \mathrm{R}^{2}=0.402, \mathrm{R}(\mathrm{bar})^{2}=0.39, \mathrm{n}=160, \mathrm{df} .=152
\end{aligned}
$$

Considering only the average schooling of the adult members and leaving job status of the head of the families we get,

$$
\begin{aligned}
& \text { 4. } \mathrm{INF}=0.089-0.0019 \mathrm{EDU} \text { (Adult) }-0.00011 \mathrm{FI}^{*}+0.0043 \text { FSIZE* } \\
& (-0.2075) \quad(-4.43) \quad(1.65) \\
& +0.011 \mathrm{LAND}+0.064 \mathrm{D}^{*}-0.014 \mathrm{SM}^{*}
\end{aligned}
$$

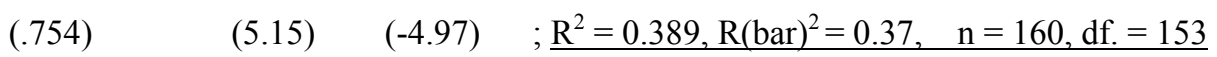

Considering job status of the head of household and leaving number of sawmills we get,

5. INF $=0.078-0.0029 \mathrm{EDU}($ Adult $)-0.00011 \mathrm{FI}^{*}+0.0045 \mathrm{FSIZE}^{* *}-0.0086 \mathrm{JOB}^{*}$

$$
\begin{array}{ccc} 
& (-0.306) & (-4.155) \\
+ & 0.0116 \text { LAND }+0.061 \mathrm{D}^{*} & (1.61) \\
(0.75) & (4.56) & \underline{\mathrm{R}^{2}=0.32, \mathrm{R}(\mathrm{bar})^{2}=.31, \mathrm{n}=160, \mathrm{df} .=153}
\end{array}
$$

Here the values of $\mathrm{R}^{2}$ are not very high, but using stepwise regression these are the best possible results observed. The result indicates that there is very insignificant impact of education on the collection of fuel-wood or percentage of income earned from forest. Actually there is high degree of variation in educational level and a very few are educated in those sample villages. Moreover, the villagers are poor and hence human development level is also low. The incidence of poverty and lack of other opportunities push them towards forest resources and more so if it is common. Both, collection of fuel-wood and earning from forest are significantly positively affected by family size and negatively related to total family income. Better job opportunity is also inversely related to the dependence of people on forest. 
Larger family size means more requirements and thus it intensifies harvest of forest. Moreover, the low educated, relatively poor village is found to have relatively large family size and hence dependence is more. The negative coefficient of FI indicates that the affluent people will be less dependent on forest. It does not mean that they do not use forest resources. What it indicates is that they devote less time for harvesting forest due to high opportunity cost of their time. Rather they collect fuel-wood, charcoal and other items from the other people as in the interior villages LPG and other fuel is not available. Also they find some locally collected items cheaper than at town and hence many of the items available in the nearby forest also find place in their daily menu though the percentage is less for the rich.

Though from the over all sample villages we find inverse relation between income and extraction of forest resource, in one village (Mawlangkhar) we observed average income of the people who extract forest is more than who do not. Actually in that village (which is also far away from town/business centre) forest and agriculture together constitutes the main occupation due to lack of other opportunities. Hence those who collect more they earn more. Moreover, a very few people own land (31 family out of 160 in total) and thus forest and hence they harvest commercially though on a limited scale and their income is therefore much more than the others in that village. That is why the distance here has significantly positive impact on collection of fuel-wood and contribution of forest to family income. Though there is limited commercial activity, it is one of their main earning sources. However, presence of sawmill (some of which are closed now) has negative impact on the percentage of earning from forest. Actually, sawmill are run through large scale commercial extraction of timber, but that is of private forest of the owners in many cases or if community forest then it provides revenue mainly to those who have better access and control over power to use it. In general poor families extract mainly for survival.

From the correlation Table 1 and flow-chart 2 as well as the regression output of the primary data we can conclude that population growth where technology and industrial development is very poor in the state like Meghalaya, has significantly positive impact on the rate of extraction of forest resources either for fuel-wood or consumption or generating revenue. The correlation between district-wise variation in population growth and per capita Net District Domestic Product during 1993 to 2000 was significantly negative; however correlation of variation in population growth with that of rural literacy rate is insignificant (here we have considered only rural literacy as more than 80 per cent of population in Meghalaya are rural. Though rising educational level is expected to raise the capacity to earn more and reduce demand for more children, and also raise awareness about the need for judicious use and preservation of forest; just mere variation in literacy is not enough and more so if the area suffers from high degree of poverty. The poorer, even if little educated, is expected to prefer more children for their future insurance and also to extract forest resources for survival where there is no other major source of sustenance (Goodstein, 1999). However, educated people may try to better manage forest resource for their survival. But that is not possible unless property right of those people is secured. Poverty level in the state has not been reduced significantly relative to other states, which is clear from the over time lowering of position at all India ranking in poverty as well as human development (Lyngkhoi, 2007).

Forest is the source of a part of income and survival of those living around it. So pattern of cooking fuel, cattle rearing and other consumption habits and thus quality of life is also partly shaped by the availability of forest resources. Also a few people earn substantial income from timber collection and that is expedited if there is better access and timber industry is there in and around the village. Even though some of the families who do not collect forest resources by themselves, forest resources become a part of their daily uses. They collect those from the others who collect such materials and sell, as these are relatively cheaper than their substitutes in the villages and more so when alternatives are not available. So, the relatively better off families also save a part of their income due to availability of forest resources.

The regression results revealed that rising income had significantly negative impact on the fuel-wood or percentage of income collected by the families from the forest and thus their dependence at the micro level. However, land holding has positive relation with the rate of fuel-wood extraction. One may think that larger the land holding means better economic condition of the family and hence less dependence and hence degradation. But, here whatever the bigger landowners earn is actually from the use of their agricultural land or forest land in the absence of any other opportunity and thus a direct impact on the forest. But the impact on percentage of earning from forest of land holding is not significant. Though at the individual household level, rising income is inversely related to the degradation of forest, from correlation table we observe, the more the contribution of forest, with other things remaining identical (technology, productivity of other sector etc) the faster is the NSDP growth. It means the area or district that has higher potential for extraction of forest resource, observes better growth of income. So in that case, it is essential to maintain a good quality forest for the sustainable growth of 
the economy. Therefore, although in general rising income is supposed to be associated with the reduction in dependence on forest, in the interior villages without alternative opportunity except farming and where forest is common, the income rises proportionately with extraction.

Collection of fuel-wood or other consumption items is positively associated with the family size, which is significant. Actually a smaller family can also extract more if they do it for commercial purposes or if their per capita consumption of such items is higher.

There is significantly positive impact of distance from nearest town at family level on the fuel-wood extraction or percentage of income earned from the forest. This is because the families of the interior village have less scope of earning from other source and most of them are poor. Also, alternatives of fuel-wood are not available in the interior areas. However, comparing the four villages on personal observation we find that the village adjacent to town or having saw-mill observes more degradation, which has been mainly due to the large scale commercial harvesting in the earlier years. Currently people of that village are relatively less dependent on forest as less resource is available and they find alternative source of income either in nearby town or generated within the village.

Moreover, distance of villagers' from the nearest forest adversely affects the amount of collection as more distance requires more time and manpower to collect the same. But here most of the families in all four villages except a few in Mawtawar are located within forest area and thus we have not considered it in our regression as another explanatory variable. Also though people of Mawlangkhar are highly dependent on forest but degradation (from personal observation) is less as they use forest mainly for subsistence, while in case of Mawtawar marketing is the primary objective and thus degradation is rapid. So even with similar population pressure degradation can be more if extraction is for commercial purposes.

Overall, the results obtained are in support of the recent IPAT analysis (Chertow, 2001) that the environmental stress and damage (here forest resources) depend largely on the heavy population growth, lack of affluence and technological backwardness. Infrastructure and institutional factors are also found important for the management and sustainable use of forest for the welfare of inhabited people.

\section{Conclusion}

In conclusion, it can be said that the livelihood pattern of the people living in and around the forest areas is highly shaped by the available forest resources that in turn affects the quality of forest. The best way to preserve forest and improve the condition of the people is to improve economic condition of the people through education and technological development, suitable cultivation approach and also to follow a judicious land use pattern so as to maintain the forest resource and its productivity, which in turn provide sustainable sustenance to the people and also improve the condition of the poorer. Participatory management has been advocated by many and thus became an alternative option for this.

Moreover, education would help in controlling population through reduced family size and raise the productivity capacity of people and lead to better management of forest resources for their sustainable benefit. Though good connectivity with the remote areas enhance the chance of commercial extraction, it may help reaching alternative fuel to the interior, increase scope of education and other opportunities to those interior people. If it is associated with simultaneous effort on social forestry, farm forestry, eco-tourism etc then it can help better management of forest. The harvesting should not be stopped as economic condition of those people is highly dependent on forest. Rather, a scientific and judicious approach can help improvement of living conditions of local populace or standard of local economy as well as better management of forest areas.

\section{References}

Aluko, M. A. O. (2004). Sustainable Development, Environmental Degradation and the Entrenchment of Poverty in the Niger Delta of Nigeria. Journal of Human Ecology: International, Interdisciplinary Journal of Man-Environment Relationship, 15(1), 63-68.

Anderson, P. (1989). The Myth of Sustainable Logging: The Case for a Ban on Tropical Timber Imports. The Ecologist, 19(5), 166-168.

Baland, J. M., Bardhan, P. K., Das, S., Mookherjee, D., \& Sarkar, R. (2006). Managing the Environmental Consequences of Growth: Forest Degradation in the Indian Mid-Himalayas. paper presented in India Policy Forum.

Bhagat, R. B., \& Hassan, Md. I. (1994). On the Relationship between Population, Underdevelopment and Environment: Are we really in Malthusian Trap? The Indian Geographical Journal, 69(2), 93-98. 
Birdsall, N. (1994). Government, Population and Poverty: A Win-Win Tale. in Lindahl-Kiessling, K. and Landberg, H. (eds.). Population, Economic Development and the Environment. Oxford University Press, pp. 173-195.

Boyce, J. K. (1994). Inequality as a Cause of Environmental Degradation. Ecological Economics, 11(3), 3-10. http://dx.doi.org/10.1016/0921-8009(94)90198-8

Chauhan, I. S., \& Chauhan, A. (1998). Environmental Degradation. Rawat Publications. Jaipur and New Delhi.

Chertow, M. R. (2001). The IPAT Equation and Its Variants: Changing Views of Technology and Environmental Impact. Journal of Industrial Ecology, 3(4), 13-29.

Cropper, M., \& Griffiths, C. (1994). The Interaction of Population Growth and Environmental Quality. American Economic Review, 84(2), 250-254.

Cruz, W., \& Gills, C. (1990). Resource Policy Reform in the Context of Population Pressure: The Philippines and Nepal in Chapman, D. (ed.) Arresting Renewable Resource Degradation in the Third World. World Bank Environment Working Paper No. 44, Washington D. C.: The World Bank.

Dasgupta, Partha, Folke, P. C., \& Maler, K. G. (1994). The Environmental Resource Base and Human Welfare. in Lindahl-Kiessling, K. and Landberg, H. (eds.), Population, Economic Development and Environment. Oxford University Press. pp. 25-50.

Datta, S. (2000). Population Growth and Natural Resource Base in Meghalaya. in Datta Ray, B. (ed.) Population, Poverty and Environment in North East India. Concept Publishing Company. New Delhi. pp. 173-182.

De, U. K. (2003). Economic Incentive and Environmental Management: A Study of Forestry in North-East India. in Husain, Z. (ed.) Environmental Issues of North East India. Regency Publications. New Delhi. pp. $170-188$.

De, U. K. (2006). Population, Poverty and The Problem of Natural Resource Management. Paper presented in the Conference on Demographic Dividend on 5-1-2006, organised by Liberty Institute in New Delhi.

Dreze, J., \& Sen, A. K. (1989). Hunger and Public Action. Clarendon Press. Oxford, London.

Dutta, R. (2000). Ecological Degradation and Forest Resources in Meghalaya. in Datta Ray, B. (ed.) Population, Poverty and Environment in North East India. Concept Publishing Company. New Delhi, pp. 382-85.

Ehrlich P. R. (1968). The Population Bomb. Sierra Club. Ballantine, New York.

Ehrlich, A. R., \& Ehrlich, P. R. (1990). The Population Explosion. New York.

Engelman \& Robert. (1997). Population as a Scale Factors: Impacts on Environment and Development. in Pachauri, R.K. and Qureshy, Lubina F. (eds.) Population, Environment and Development. Tata Energy Research Institute, New Delhi, pp. 15-33.

FAO. (1993). Strategies for Sustainable Agriculture and Rural Development: The Role of Agriculture, Forestry and Fisheries. Rome: United Nations Food and Agriculture Organisation.

Gill, M. S. (1999). Population and Environment in District Leh (Ladakh), Jammu and Kashmir). Population Geography - a Journal of the Association of Population Geographers of India, 21(1 and 2), 19-30.

Goodland, R. (1991). Tropical Deforestation Solutions, Ethics and Religions. World Bank Environment Working Paper. Washington D. C.: The World Bank.

Goodstein, E. S. (1999). Economics and the Environment. (2nd ed.). Chapter on Poverty, Population and the Environment. Prentice Hall. New Jersey, 429-460.

Grossman, G., \& Krueger, A. (1995). Economic Growth and the Environment. The Quarterly Journal of Economics, 353-377. http://dx.doi.org/10.2307/2118443

Hardin, G. (1968). The Tragedy of the Commons. Science, 162, 124-48.

Husain \& Zahid. (1994). Ecological Implications of Population Growth in North East India, in Mukherjee, S (ed.) Demographic Profile of North East India. Omsons Publications, New Delhi, 116-126.

Ives, J. D., \& Messerli, B. (1988). The Himalayan Dilemma, London: Routledge.

Jaganathan, N. V. (1989). Poverty, Public Policies and the Environment, World Bank Environment Working Paper No. 24, Washington DC: The World Bank. 
Johnson, D. G. (2000). Population, Food and Knowledge, The American Economic Review, 90(1), 1-14. http://dx.doi.org/10.1257/aer.90.1.1

Joshi, B. K. (1990). Poverty, Inequality and the social Structure, in Tarlak Singh (Ed), Social Science Research and Problem of Poverty, Concept Publishing Company, New Delhi, p. 147.

Kuri, P. K. (2005). Common Property Resources, Environmental Externalities and Tribal Poverty in Arunachal Pradesh, Unpublished UGC Sponsored Major Project Report, University of Burdwan.

Lamin \& Henry. (1995). Economy and Society in Meghalaya, Har-Anand Publications, New Delhi.

Lyngkhoi, W. (2007). Population, Poverty and The Degradation of Forests: A Contemporary Analysis of Meghalaya, Unpublished $\mathrm{PhD}$ thesis, North-Eastern Hill University, Shillong.

Macneill, J. (1989). Strategies for Sustainable Economic Development, Scientific American, 261(3), 104-113. http://dx.doi.org/10.1038/scientificamerican0989-154

Malthus, T. R. (1798; 1992). An Essay on the Principles of Population, Cambridge, Cambridge University Press.

Meadow, D. H., et al. (1972). The limits to Growth, Universe Books, New York.

Mink, S. D. (1993). Poverty, Population and the Environment, World Bank Discussion Paper 189, The World Bank, Washington D. C.

Neena. (2000). Natural Resources Management for Sustainable Development (Land, Forests and Biodiversity), in N. Rajalakshmi (Ed). Environment and Economic Development. Manak Publications, New Delhi, pp. 284-294.

Reidhead, P. W., Qureshy, L. F., \& Narian, V. (1997). Population, Environment and Development: Interactions and Issues, in R. K. Pachauri and Lubina F. Qureshy (Eds). Population, Environment and Development, Tata Energy Research Institute, New Delhi, pp. 45-61.

Purkayastha, Subrata. (2000). Impact of Population Growth on the Present Civic Amenities within the Shillong Urban Agglomeration, in B. Datta Ray (Ed), Population, Poverty and Environment in North East India, Concept Publishing Company, New Delhi. pp. 183-86.

Repetto, R. (1990). Deforestation in the Tropics, Scientific American, 262(4), 36-45. http://dx.doi.org/10.1038/scientificamerican0490-36

Sanchez, F. M. (1998). Linkage between Poverty and Environmental Degradation- A Profound Opinion, in H. S. Sharma and S. Chattopadhyay (Eds), Sustainable Development - Issues and Case Studies, Concept Publishing Company, New Delhi.

Sen, Amartya. (1994). "Population and Research: Food, Fertility and Economic Development," in Lindahl-Kiessling, K. and H. Landberg (Eds), Population, Economic Development and Environment, Oxford University Press. pp. 51-74.

Simon, J. (1981). The Ultimate Resource. Princeton University Press, Princeton, USA.

Simon, J. (1996). The Ultimate Resource 2. (2nd ed.). Princeton University Press, Princeton, USA.

Simon, J., \& Myers, N. (1994). Scarcity or Abundance? A Debate on the Environment, Norton, New York.

Singh, B. P. (1987). The Problem of Change: A Study of North East India, Oxford University Press, New Delhi.

Somanathan, E. (1991). Deforestation, Property Rights and Incentives in Central Himalayas. Economic and Political Weekly, January 26th.

Southgate, D. (1988). The Economics of Land Degradation in the Third World, World Bank Environment Working Paper No. 2, Washington DC: The World Bank.

Subedi, B. P. (1997). Population and Environment Interrelationships: The Case of Nepal, in R. K. Pachauri and Lubina F. Qureshy (Eds), Population, Environment and Development, Tata Energy Research Institute, New Delhi, pp. 191-213.

World Bank. (1987). Environmental Growth and Development, Development Committee Pamphlet 14, World Bank, Washington D. C.

World Bank. (1988). Environment and Development: Implementing the World Bank's New Policies, Development Committee Pamphlet 17, World Bank, Washington D. C. 